\title{
Transforming Development with Grassroots Planning in Madhya Pradesh, India
}

Commonwealth Journal of Local Governance

Issue 11: December 2012

http://epress.lib.uts.edu.au/ojs/index.php/cjlg

\section{Yogesh Mahor}

Senior Social Development Planner

Poverty Monitoring and Policy Support Unit

Madhya Pradesh State Planning Commission, Bhopal

\author{
Ram Gopal Singh \\ Professor of Social Science
}
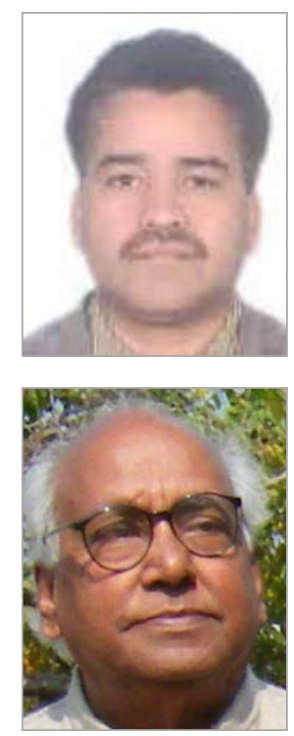

\begin{abstract}
There is growing acknowledgment that state interactions must take place in a democratic context. This has been accompanied by attempts to foster forms of democratic governance that provide scope for citizen participation in the development process. However, due to vast inter- and intra-country differences, no single model has emerged for countries to follow, even if each effort has contributed to further deliberation and discussion.
\end{abstract}

A major challenge to successful implementation has been the absence of an effective and practical framework to ensure decentralization. In the state Madhya Pradesh of India, the democratic reform has progressed from conceptualization to mobilization to institutionalization. For the first time in Madhya Pradesh's development history, state government has shown the courage to interact with communities in making village-level development plans. The Madhya Pradesh Planning Commission has created a tangible plan for working more closely with communities.

This paper outlines the nature of this initiative and analyses the adequacy of the framework for decentralizsation and the mechanism of governance adopted by the Madhya Pradesh government for achieving the goal of participatory democracy. In particular, the paper assesses the state model of decentralized planning, its operational framework, and ongoing efforts. It also presents the status of village-level planning in the state, including how villages are interacting with one another and with government entities outside the state.

Key words: Decentralized district planning; inclusive growth; convergence' micro-planning. 


\section{Theoretical Framework for Decentralization}

From the launch of India's first Five Year Plan in 1951, the Government of India has made several attempts to establish decentralized socio-economic development planning. During the last 62 years, the planning process of the nation has undergone several changes. Though broad objectives remained more or less the same, strategies and techniques vary from plan to plan to meet the needs of the time. In spite of these changes the basic system of centralized and departmental planning remains oldfashioned and top-down, thereby losing significant amounts of local and sometimes expert information.

D. R. Gadgil, former Vice Chairman of the National Planning Commission of India once remarked:

The present mood is to talk about village democracy but to deny real power even to the states. Planning at the state level means official compilation of schemes which may prove acceptable to the centre. of course, non-official workers, experts or productive enterprises, are nowhere in the picture in their own region.

This is one of the reasons why planning has not been able to meet the basic needs of the people. There has been a continuous struggle towards evolving a form of democratic governance that can provide scope for citizens' participation. The 73rd and 74th Constitutional amendments made it compulsory to constitute the District Planning Committees (DPCs) in the State, the State Finance Commission together with the constitution of three-tier Panchayat system, and Urban Local Bodies ${ }^{37}$. Similarly, Under Article 243 (z) (d) of the Constitution, District Planning Committees have a mandatory and critical function of formulating district plans, and monitoring and evaluation at the district level.

\section{Methodology}

In order to collect qualitative information on several aspects of planning and service provisions at the local level, fieldwork was conducted in nine districts and the State Planning Commission of Madhya Pradesh during 2-22 June 2012. Focus group discussions were held with villagers, grassroots workers, women's groups and members of Panchati Raj Institutions and NGO partners.

The State government has set up a steering committee headed by the Chief Minister to undertake Decentralized District Planning in Madhya Pradesh. This committee provides overall policy guidance and direction for implementing development plans. Overseeing of the implementation is done by the working group led by the Member Secretary of the State Planning Commission.

\footnotetext{
${ }^{37}$ Local government is divided between Panchayats (rural authorities) and Urban Local Bodies (municipalities). In states with a three-tier system of rural authorities there is a division of duties. Zila Panchayats have general finance and audit, planning, social justice, education, health, agriculture and industrial committees. Panchayat Samati have environment, amenities and economic responsibilities. Gram Panchayats (village level) have production, social justice and amenities committees (CLGF 2009).
} 
The Government of Madhya Pradesh initiated the decentralized planning process in five districts Khargone, Rajgarh, Satna, Chattarpur and Mandla of Madhya Pradesh in the year 2009-10. Plans were prepared in bottom-up manner, starting from the grassroots i.e. villages in the rural areas and wards in the urban areas, with participation of the community and facilitation by government functionaries and volunteer organizations. Based on this initial experience, the Government of Madhya Pradesh planned to scale up the process of Decentralized District Planning in all the 50 districts of the State from the year 2010 onwards. The existing structure of Decentralized District Planning at the district level for rural and urban areas is illustrated in Figures 1 and 2.

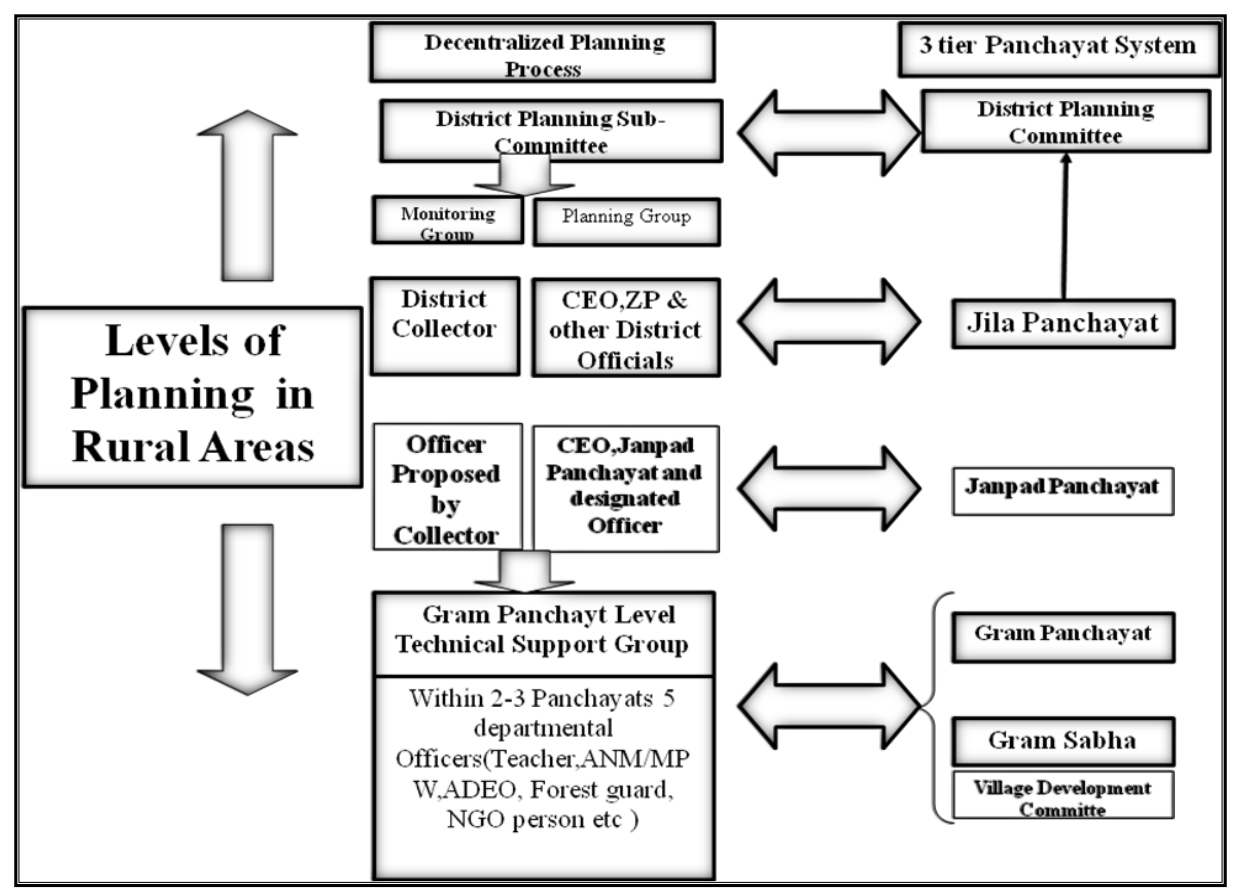

Figure A - Rural decentralized planning flow chart 


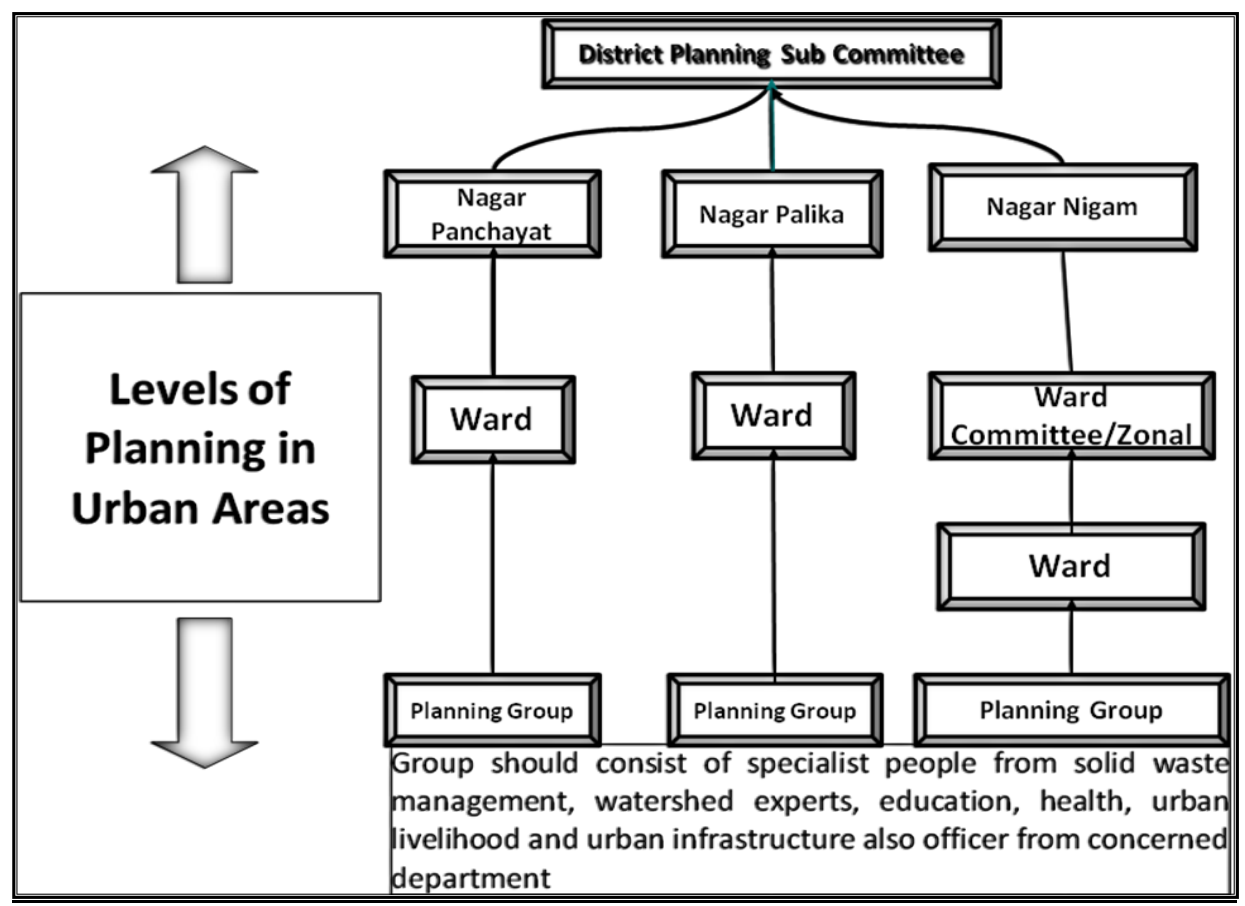

Figure B - Urban decentralized planning flow chart

The State Planning Commission (SPC) of Madhya Pradesh has provided guidelines for the preparation of decentralized plans covering all critical processes and activities. The main features of the guidelines are as follows:

- The SPC will provide technical and financial facilitation for the preparation of the district plan and communicate the overall plan ceiling for the districts.

- DPCs in consultation with specialists, officials, voluntary organizations and other stakeholders will determine the budget for the financial plan and split between rural and urban programmes, and formulate strategy to prepare and integrate plan proposals of Local Bodies (Panchayats and Urban Local Bodies).

- With support from the Technical Support Group (TSG), rural plans will be prepared by Panchayat Raj institutions ${ }^{\mathbf{3 8}}$ and urban plans will be prepared by Urban Local Bodies. TSGs were developed to support three to five Gram Panchayat (village wards), and comprise five to six grassroots level government functionaries who supported the Village Development Committee of the Gram Sabha (village development committee) in the planning process.

- Local bodies are encouraged to develop an area focus vision of development, based on local needs and specific strengths.

- The plans prepared at Gram Panchayat wards and Urban wards are integrated and consolidated at each subsequent level, finally to be consolidated at the district level. This is further submitted to the DPC for approval and consolidation.

\footnotetext{
${ }^{38}$ Panchayat Raj refers to all levels of Panchayat rural governments
} 
- All the line departments are grouped into key sectors. Further working groups will be constituted for each sector for preparing proposals, and possible inter- and intra-sector convergences (Figure 3). Working groups will also prepare position papers for the achievement of Millennium Development Goals at their levels.

Figure 3: Sector-specific convergence among selected departments

\begin{tabular}{|l|l|}
\hline Sector & Concerned Departments / Agencies \\
\hline Education & $\begin{array}{l}\text { School education, higher education, technical education, non-formal } \\
\text { education, vocational education. }\end{array}$ \\
\hline Health \& Nutrition & $\begin{array}{l}\text { Public health and family Welfare, public health engineering, woman and child } \\
\text { development, food and civil supplies. }\end{array}$ \\
\hline $\begin{array}{l}\text { Livelihood } \\
\text { veterinary and dairy, village industries, social justice, water resource, } \\
\text { fisheries, handloom, cooperation, sericulture, welfare of SC, ST and OBCs. }\end{array}$ \\
\hline $\begin{array}{l}\text { Managragement } \\
\text { Energy } \\
\text { Management }\end{array}$ & $\begin{array}{l}\text { PWD, rural development, rural engineering service, water resource, energy, } \\
\text { planning. }\end{array}$ \\
\hline $\begin{array}{l}\text { Civil Rights } \\
\text { Protection }\end{array}$ & Energy, rural development, electricity, forest, planning. \\
\hline
\end{tabular}

\subsection{Preparing village micro-plans}

With information learnt from the pilot work, unique processes for the preparation of district plans have been rolled out as follows;

- Each Gram Sabha follows a participatory process, with the help of the Technical Support Group (grassroots functionaries, voluntary organizations, different sectoral experts and community based workers), to come up with "a vision of development" based on local needs.

- Local community needs are captured with the facilitation of TSG on customized input formats.

- The Gram Sabha prepared their proposal for different sectors in consultation with all the stakeholder(s), especially with poor villagers, Scheduled Castes, Scheduled Tribes and women;

- The proposal of each Gram Sabha is consolidated by preparing the overall plan proposal for the Gram Panchayats. The Janpad Panchayat (next tier) consolidates the plan proposals of all concerned in the Gram Panchayats, including the Block-level interventions.

- In addition to the district level interventions, plans prepared by Janpad Panchayat form the basis for consolidating the plan at Zila Panchayat level. 


\subsection{Preparing urban micro-plans}

- Urban local bodies have also formed TSGs or working groups consisting of their functionaries, members of Ward Parishad, retired government staff and individuals from the ward to provide technical support to Mohalla Samiti ${ }^{39}$, in the process of participatory urban planning.

- The participatory micro plans prepared at the Mohalla and the ward level were consolidated at the Urban local body level with the integration of interventions spreading over more than one ward or sector.

\subsection{Citizens' engagement}

In order to engage citizens in decentralized planning, budgeting and monitoring, the MPSPC has provisioned a participatory planning process initiated at the community level.

Communities, voluntary organizations, paralegal village committees, child clubs, ward citizens' forums, SHGs and TSGs are key players that have to be consulted in order to engage citizens and ensure inclusion of their voice and priorities in the local decentralized planning cycle. Furthermore, the Decentralized District Planning (DPP) framework demands the participation of Scheduled Castes, Schedule Tribes and other disadvantaged groups in the planning, implementation and monitoring processes.

The following mechanisms are able to directly or indirectly influence decisions within the planning cycle and hold service providers accountable to citizens to some extent:

- Social mobilization targeted at disadvantaged groups empowers deprived families to raise their voice in discussions on local needs and provides an opportunity to link them with local service providers.

- The planning commission envisages that groups for Scheduled Castes, Scheduled Tribes, other disadvantaged groups, and women's forum based committees are established by Local Bodies (local planning units and institutions government). This enables them to contribute to local planning, budgeting and implementation processes by expressing their equity concerns and interests.

- Gram Sabha (village councils) include demand-side members, as well as representatives from disadvantaged groups, to ensure that ordinary citizens and the deprived are able to have a voice in local planning and management of local development activities.

\footnotetext{
${ }^{39}$ Moahllas are considered the neighbourhood areas within an urban ward where a group of families live together. Mohalla Samiti (neighbourhood councils) were formed to improve consultation - in rural areas people had Gram Sabhas as a forum for participation, but there was no equivalent in urban areas
} 
- Citizens' charters, social audits, wall notices at Panchayat buildings and public hearings are tools and platforms for developing accountability and transparency, and providing feedback to ensure that plans are more citizen-responsive.

- The provision for publicizing budget allocations and programme activities through various forms of media provides an opportunity for local people to raise their voices and advocate for resources that support projects for their benefit.

\subsection{Plan integration and consolidation}

The DPC after receiving rural and urban micro-plans, consolidates all plans at the district level with the help of district level planning group. The integrated plan as finalized by the District Planning Committee will ensure clarity on the roles of various departments. The plan will be submitted to State Planning Commission (SPC) after due deliberation in the district planning Committee. To support the consolidation at the higher tiers of Rural and Urban Local Bodies, customized software is also being developed.

\section{From conceptualization to institutionalization: state leadership in DPP}

Several initiatives are seen as key to effective implementation of Decentralized District Planning (DPP).

- A Steering Committee formed at the state level under the chairmanship of the Chief Minister, and a working group headed by the Member Secretary of the State Planning Commission, provides policy support and guidance for effective plan implementation;

- State-specific manuals, customized training modules, and planning input formats were developed for each level (Gram Panchayat (Village), Urban Ward, Block etc.) keeping in mind the requirements of the software applications;

- The selection of state level Technical Support Institutions (TSI) who are domain experts in decentralized planning process was important to support development activities. Around 11 TSIs have been formed for training and capacity building activities throughout the planning cycle;

- Micro-planning workshops and Trainings of Trainers (TOT) were conducted in all districts and block level with the technical support of resource organizations like Poverty Monitoring and Policy Support Unit, and international organisations such as UNICEF, UNDP, and DFID and others;

- Resource people and around 70,000 functionaries, including members of TSGs have been given training as part of this year's roll out; 
- Planning software was developed to facilitate the data entry and analysis of data at each level of planning;

- Improved web based software was developed which is now facilitating further analysis, planning and online monitoring. Web-based software enables local involvement in generating plans for Janpad Panchayat, Gram Panchayat, and Urban Local Bodies;

- Planning processes (as detailed in the manual) were initiated; sector- wide data analysis was done and activity- scheme linkages were made keeping a focus on convergence;

- Information generated through village/ward plans is being included into appropriate departmental plans;

- Plans are consolidated by higher planning units and finally approval by the District Planning Committees;

- A number of workshops for sharing the knowledge and learning from the Decentralized District Planning process were organized at different levels;

- The National Planning Commission has also appreciated the approach in Madhya Pradesh and suggested that other should replicate the unique process of planning adopted by the MP State Planning Commission.

Although the legislative and policy framework is supportive of decentralization to the local level, in practice, it has not progressed as far or as effectively as envisaged by the policy. The structures of grassroots institutions at both rural and urban level both need to be empowered to improve the effectiveness of development, accelerate the rate of socio-economic growth, and ensure inclusive growth. The real involvement of Panchayat Raj Institutions (PRIs - rural local governments) and Urban Local Bodies (ULBs - municipalities) in development planning, monitoring and evaluation is a major milestone to be achieved. The presence of mature institutions of local self governance in the State provides an unique opportunity to translate budgetary outlays in to better outcomes.

\section{Decentralized District Planning: a powerful tool of accountability and convergence.}

Based on the learning experiences of the pilot stage, the state government has scaled up the process and rolled out Decentralized District Planning (DPP) in all 50 districts from the year 2010-11 onwards. Government institutionalized the DPP by allocating about $38 \%$ of state financial resources to district control, known as "District Plan" allocations. The total allocation for District Plans for the financial year 2012-13 is about $37 \%$ of total budget for the State economic plan. An impressive 42,358 rural and urban micro-plans were prepared in a bottom-up manner starting from the grassroots level i.e. from villages in rural areas and wards in urban areas, with participation by the community and facilitation by government staff. 
We may, therefore, conclude by saying that questions about quality, sustainability, equity, and longterm effects on the service delivery and the overall system will only be answered in due course. On the basis of national and international experience, we see a potential benefit for Decentralized District Planning with an optimum level of participation that encourages demand for services in the community. Strategies should, however, be designed to take into account best practices and evidence, and they should promote equity. Rigorous monitoring and assessment should be built in and the initiatives should not be allowed to simplify political generosity.

Once this planning process is rolled out in practice in Madhya Pradesh, the following outcomes will be achieved:

- Strengthening institutions of local self governance in the state as per the provisions of the Constitution.

- Building the capacity of the institutions of local self governance in implementation of the programs and delivery of essential public services.

- Increased ownership of the works to ensure better operation and maintenance

- Streamlining the process of planning being undertaken under centrally sponsored flagship national programs like- Mahatma Gandhi National Rural Employment Scheme (MGNREGS), Total Sanitation Campaign (TSC) and National Rural Health Mission (NRHM) etc

- Convergence between programs at the grass-root level will ensure better allocation of resources and increased outcomes

- Advance planning will improve the capacity for timely fund utilization of 3 Fs. i.e. Fund, Functions and Functionaries at the field level.

\section{Learning}

Although Madhya Pradesh has developed a significant framework for decentralized the planning process realistically, local planning practice is still mostly top-down, with participatory planning not fully operational. Guidance is not always followed and institutions that should be involved are not participating because an enabling environment has yet to be created at the local level. As a result, duplication and overlap are also observed at all levels, hampering efficiency and diluting results.

In general, citizens and voluntary organizations need to better informed about the provisions made in various policies and guidelines for their engagement in local governance. Therefore, they are not often able to claim their rights to participate in decision-making processes. Most voluntary organizations have limited capacity and are unable to engage meaningfully in all steps and processes of decentralized planning in order to raise their voice and have an influence on decision-making. There is a requirement to enhance convergence of the local planning process to bring about synergies and backward and forward linkages. It's now high time to strictly adopt participatory planning processes 
and link with social mobilization programmes and to build a network of service providers working at

local level for integrated planning and budgeting.

\section{Bibliography}

Alsop, R.J. and Krishna, A. and Sjoblom, D (ed Forusz, S.) (2009) Inclusion and Local Elected Governments, The Panchayat Raj System in India” published by World Bank's Social Development Family Washington, D.C.: World Bank

Behar, A. and Kumar, Y. (2002) Decentralization in Madhya Pradesh, India: From Panchayati Raj to Gram Swaraj, Working Paper 170. London: Overseas Development Institute, http://www.odi.org.uk/sites/odi.org.uk/files/odi-assets/publications-opinion-files/2702.pdf, accessed November 2012

Cheema, GS and Rondinelli, DA (ed.) (1983) Decentralisation and Development: Policy Implementation in Developing Countries, New Delhi: Sage Publications

CLGF 2009) Country profile: India, http://www.clgf.org.uk/userfiles/1/files/India\%20local\%20government\%20profile\%202011-12.pdf, accessed November 2012

Desai, V. (1990) Panchayati Raj: Power to the People”, Bombay: Himalaya Publishing House, p.4

GoMP (1995) Madhya Pradesh District Planning Committee Act, GoMP (State Planning Commission)

GoMP (2012) State Planning Commission, Government of Madhya Pradesh, India, www.mp.gov.in/spb, accessed February 2012

Mathew, G. (1995) Status of Panchayati raj in the states of India, New Delhi: Institute of Social Sciences Manual for Intergraded district planning, PMPSUS, MPSPC, Govt of MP 2008.

PRIA (2005) Engaging Mohalla Vikas Samitis, http://www.pria.org/publication/Engaging\%20Mohalla\%20Vikas\%20Samitis\%20\%20Synthesis\%20Paper.p df, accessed November 2012

UNDP (2001) Decentralization in India, Challenges \& Opportunities published by UNDP (United Nations Development Programme) New Delhi. 